\title{
Effect of presynchronization with human chorionic gonadotropin or gonadotropin-releasing hormone 7 days before resynchronization of ovulation on fertility in lactating dairy cows
}

\author{
J. O. Giordano, M. C. Wiltbank, J. N. Guenther, M. S. Ares, G. Lopes Jr., M. M. Herlihy, and P. M. Fricke ${ }^{1}$ \\ Department of Dairy Science, University of Wisconsin, Madison 53706
}

\begin{abstract}
Our objectives were to (1) compare the effect on pregnancies per artificial insemination $(\mathrm{P} / \mathrm{AI})$ of presynchronization of the estrous cycle with human chorionic gonadotropin (hCG) $7 \mathrm{~d}$ before resynchronization of ovulation (Resynch) initiated 25 d after timed artificial insemination (TAI) and compare the presynchronization treatment with the Double-Ovsynch (DO) protocol, and (2) evaluate whether hCG for presynchronization could be replaced with GnRH. In experiment 1, lactating Holstein cows were blocked by parity and were randomly assigned to receive (1) Resynch-25 (D25), the Resynch protocol (GnRH-7 d-PGF ${ }_{2 \alpha}-56$ h-GnRH-16 hTAI) initiated $25 \mathrm{~d}$ after TAI $(\mathrm{n}=418)$; (2) HGPG, presynchronization with hCG (2,000 IU of Chorulon) $7 \mathrm{~d}$ before D25 ( $\mathrm{n}=450)$; and (3) DO (Pre-Resynch, GnRH-7 d-PGF ${ }_{2 \alpha}-72$ h-GnRH; Breeding-Resynch, GnRH-7 d-PGF $2 \alpha-56$ h-GnRH-16 h-TAI) initiated 22 $\mathrm{d}$ after TAI $(\mathrm{n}=405)$. At $29 \mathrm{~d}$ after TAI, cows in the HGPG $(37.3 \%)$ and DO (35.8\%) groups had more P/ AI than did cows in the D25 group (28.0\%), and cows in the HGPG and DO groups continued to have more $\mathrm{P} / \mathrm{AI}$ than did cows in the D25 group at $53 \mathrm{~d}$ after TAI. Presynchronization with hCG induced ovulation in $76 \%$ of the cows, which increased the percentage of HGPG cows with a corpus luteum at the initiation of Resynch compared with cows in the D25 group. In experiment 2 , the D25 $(\mathrm{n}=368)$ and HGPG $(\mathrm{n}=338)$ treatments described in experiment 1 were compared in addition to a third treatment (GGPG; $\mathrm{n}=351$ ), in which the hCG injection $18 \mathrm{~d}$ after TAI was replaced with a GnRH injection (200 $\mu \mathrm{g}$ of gonadorelin). At $32 \mathrm{~d}$ after TAI, cows in the HGPG group had more P/AI than did cows in the D25 group (33.7 vs. 25.5\%), whereas cows in the GGPG group had intermediate P/AI (31.6\%). At $53 \mathrm{~d}$ after TAI, P/AI tended to be greater for cows in the HGPG group than for those in the D25 group, whereas $\mathrm{P} / \mathrm{AI}$ for cows in the GGPG group did not differ from
\end{abstract}

Received October 10, 2011.

Accepted June 14, 2012

${ }^{1}$ Corresponding author: pmfricke@wisc.edu that for cows in the D25 group. Treatment with hCG and GnRH $18 \mathrm{~d}$ after TAI induced ovulation in 58.8 and $48.2 \%$ of cows, respectively, but did not increase the percentage of cows with a corpus luteum at the initiation of Resynch. More cows in the HGPG and GGPG groups had their estrous cycles synchronized after the resynchronization protocols compared with cows in the D25 group. We conclude that presynchronization with hCG increased fertility by increasing synchronization to the Resynch protocol, whereas presynchronization with GnRH improved synchronization to the Resynch protocol but did not improve fertility when compared with no presynchronization or presynchronization with hCG.

Key words: presynchronization, human chorionic gonadotropin, resynchronization, dairy cow

\section{INTRODUCTION}

An effective reproductive management program maximizes the rate at which cows become pregnant after the end of the voluntary waiting period and decreases the number of cows leaving the herd because of reproductive failure. A common management scheme for first postpartum AI is to presynchronize the estrous cycle before starting the Ovsynch protocol (Pursley et al., 1995). These presynchronization programs consist of 2 doses of $\mathrm{PGF}_{2 \alpha} 14 \mathrm{~d}$ apart (Presynch) with the second $\mathrm{PGF}_{2 \alpha}$ injection given 11 to $14 \mathrm{~d}$ (Moreira et al., 2001; El-Zarkouny et al., 2004; Navanukraw et al., 2004; Galvão et al., 2007) before Ovsynch, a full Ovsynch protocol $7 \mathrm{~d}$ before Ovsynch-56 [Double-Ovsynch (DO); Souza et al., 2008], or a $\mathrm{PGF}_{2 \alpha}$ injection $2 \mathrm{~d}$ before a GnRH injection followed by Ovsynch-56 6 d later (Bello et al., 2006). When compared with the Ovsynch protocol alone, some of these presynchronization programs improve P/AI for first-service AI (Moreira et al., 2001; El-Zarkouny et al., 2004; Navanukraw et al., 2004). Nevertheless, even when these presynchronization protocols are applied correctly, $\mathrm{P} / \mathrm{AI}$ varies between 40 and $50 \%$. Thus, the significant proportion of cows that fail to conceive after first service should be rapidly detected and enrolled in efficient resynchronization of ovulation 
protocols that maximize fertility while minimizing the interval between 2 successive inseminations (Giordano et al., 2012a). The major effect of a resynchronization program may be observed in herds that rely heavily on timed AI (TAI) for AI services or those that fail to identify cows in estrus after a previous AI.

Because presynchronization programs improve the fertility of lactating dairy cows at first AI (Moreira et al., 2001; El-Zarkouny et al., 2004; Navanukraw et al., 2004), novel strategies to presynchronize the estrous cycle before initiation of resynchronization of ovulation (Resynch) protocols are now being developed. Extending the interval between 2 successive inseminations is the major limitation of using presynchronization for resynchronized breedings because these resynchronization protocols can be implemented only after the pregnancy status of a cow is known. Indeed, P/AI can be improved by presynchronizing the estrous cycle before Resynch with either a single injection of $\mathrm{PGF}_{2 \alpha} 14 \mathrm{~d}$ before Ovsynch-56 (Silva et al., 2007), a single injection of GnRH 7 d before Cosynch-72 (Dewey et al., 2010), or a modified Ovsynch protocol $7 \mathrm{~d}$ before Ovsynch-56 (DO Resynch; Giordano et al., 2012c).

A successful protocol to presynchronize the estrous cycle would ideally induce a high ovulatory response so that the percentage of cows with a functional corpus luteum $(\mathbf{C L})$ at the initiation of Resynch is maximized (Giordano et al., 2012c). A caveat of presynchronization strategies that use $\mathrm{GnRH}$ is that either all or some of the GnRH injections of the protocol may have to be administered before the CL from the previous ovulation has regressed. Because the ovulatory response to a $\mathrm{GnRH}$ injection in part depends on the pituitary release of LH, which is affected by circulating progesterone (P4; Colazo et al., 2008; Dias et al., 2010; Giordano et al., 2012a), a potential alternative to overcome the suppressive effect of $\mathrm{P} 4$ on ovulation is the use of agents capable of inducing ovulation when $\mathrm{P} 4$ is high. Human chorionic gonadotropin (hCG) may effectively induce ovulation in a high-P4 environment because, as opposed to the pituitary-mediated mechanism of action of $\mathrm{GnRH}, \mathrm{hCG}$ triggers ovulation by binding directly to LH receptors in the follicle (Ireland and Roche, 1982; 1983). Another alternative might be to increase the dose of GnRH to overcome the suppressive effect of P4 on the pituitary release of LH (Dias et al., 2010; Giordano et al., 2012a) and increase the ovulatory response in lactating dairy cows (Giordano et al., 2009).

The objective of experiment 1 was to determine if cows presynchronized with hCG $7 \mathrm{~d}$ before initiating Resynch 25 [Ovsynch-56 (GnRH-7 d-PGF ${ }_{2 \alpha}-56$ h$\mathrm{GnRH}$ ) initiated $25 \mathrm{~d}$ after a previous TAI] would have increased fertility compared with nonpresynchronized cows and would have similar fertility as cows presyn- chronized with the DO Resynch protocol. In a second experiment, we evaluated whether a $200-\mu \mathrm{g}$ dose of GnRH could replace hCG and whether the fertility of presynchronized cows using either hCG or GnRH would be increased compared with that of nonpresynchronized cows. We hypothesized that presynchronization of the estrous cycle $7 \mathrm{~d}$ before the resynchronization of ovulation starting $25 \mathrm{~d}$ after TAI would result in a greater percentage of cows with a functional CL at the initiation of Resynch, thereby increasing fertility compared with nonpresynchronized cows and similar to that of cows resynchronized with a DO Resynch protocol. Moreover, we hypothesized that GnRH would be a viable alternative to replace hCG for presynchronization $7 \mathrm{~d}$ before the initiation of Resynch.

\section{MATERIALS AND METHODS}

\section{Animals and Management for Experiments 1 and 2}

The cows used for these experiments were lactating Holsteins from a commercial dairy in south-central Wisconsin (Brodhead, WI) milking approximately 1,600 cows. Experiment 1 was performed from November 2008 to June 2009, whereas experiment 2 was performed from June 2009 to December 2009. Cows were housed in free-stall barns with ad libitum access to feed and water and were fed a TMR diet once a day. The diet was formulated to meet or exceed NRC requirements (NRC, 2001) for high-producing lactating dairy cows. Throughout both experiments, cows were milked 3 times daily at approximately 8 -h intervals, and all cows received subcutaneous injections of bST (Posilac, 500 mg; Monsanto Co., St. Louis, MO) every 14 d beginning at approximately $60 \mathrm{~d}$ postpartum. The rolling herd average was $12,982 \mathrm{~kg}$, and average daily milk yield was $40 \mathrm{~kg} / \mathrm{cow}$ per day, with $3.4 \%$ fat and $3.1 \%$ protein. All procedures, including injections, ovarian ultrasonography, pregnancy diagnosis, blood collection, and TAI, were performed while cows were restrained in self-locking head gates at the feed line.

\section{Experiment 1: Treatments}

Every week, a cohort of cows at various DIM and having at least 1 previous AI service were blocked by parity (primiparous vs. multiparous) and were randomly assigned to 1 of 3 resynchronization of ovulation treatments to receive their second and subsequent postpartum TAI. Cows were resynchronized by starting the Ovsynch protocol $25 \mathrm{~d}$ after a previous TAI (D25, control), the DO protocol beginning $22 \mathrm{~d}$ after a previous TAI, or presynchronization with hCG $7 \mathrm{~d}$ before beginning D25 (HGPG; Figure 1). All first-service 


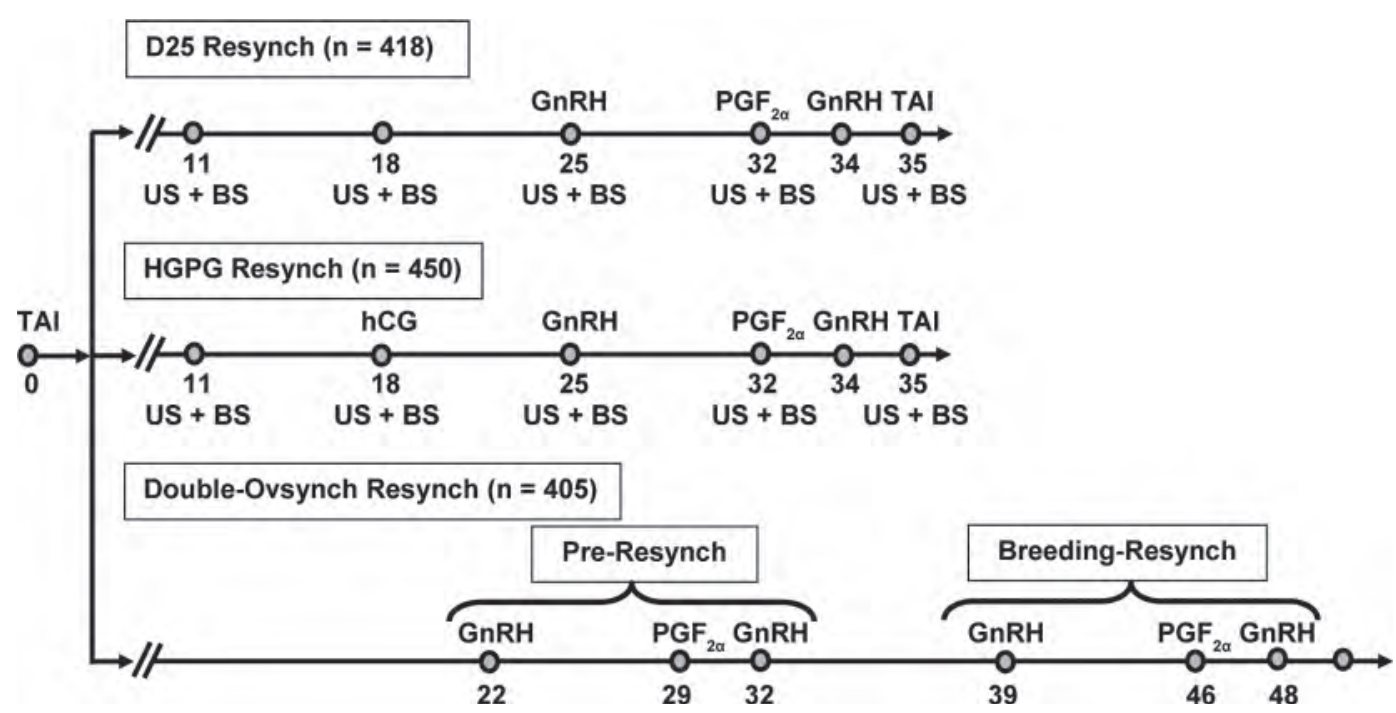

Figure 1. Schematic representation of treatments for experiment 1. Eleven days after a previous AI service, lactating Holstein cows were randomly assigned to resynchronization of ovulation with the Ovsynch protocol $25 \mathrm{~d}$ after a previous timed AI (TAI; D25 Resynch), or the Double-Ovsynch protocol beginning $22 \mathrm{~d}$ after a previous TAI, or presynchronization with hCG $7 \mathrm{~d}$ before beginning D25 (HGPG Resynch) to receive their subsequent TAI service. Ovarian ultrasound (US) was performed in a subgroup of cows $(\mathrm{n}=92)$ from the D25 and HGPG Resynch protocols at 11, 18, 25, and $32 \mathrm{~d}$ after TAI to record the number and size of structures present on the ovaries, and blood samples (BS) were collected to determine progesterone concentrations.

TAI were performed after synchronization of ovulation using a DO protocol (Souza et al., 2008).

All cows in the D25 group received an intramuscular injection of $\mathrm{GnRH}(200 \mu \mathrm{g}$ of gonadorelin diacetate tetrahydrate, Fertagyl; Intervet Animal Health, Millsboro, DE) $25 \mathrm{~d}$ after TAI regardless of their pregnancy status. Cows $(\mathrm{n}=418)$ diagnosed not pregnant using transrectal ultrasound (US) $29 \mathrm{~d}$ after TAI continued the protocol by receiving an intramuscular injection of $\mathrm{PGF}_{2 \alpha}(750 \mu \mathrm{g}$ of cloprostenol sodium, Estrumate; Schering-Plough Animal Health, Summit, NJ) 3 d later $32 \mathrm{~d}$ after TAI, and then received an intramuscular injection of GnRH $(100 \mu \mathrm{g}) 56 \mathrm{~h}$ after $\mathrm{PGF}_{2 \alpha}$, and TAI 16 to $20 \mathrm{~h}$ later (Figure 1). All cows in the DO received the first GnRH $(100 \mu \mathrm{g})$ injection of the Pre-Resynch portion of the DO protocol $22 \mathrm{~d}$ after TAI regardless of their pregnancy status. At $29 \mathrm{~d}$ after TAI, cows were diagnosed for pregnancy using US, and cows diagnosed not pregnant $(\mathrm{n}=405)$ received $\mathrm{PGF}_{2 \alpha}(500 \mu \mathrm{g})$ and then GnRH $(100 \mu \mathrm{g}) 72 \mathrm{~h}$ later to complete the PreResynch portion of the DO protocol. Seven days later, cows began the Breeding-Resynch portion of the DO protocol by receiving $\mathrm{GnRH}(200 \mu \mathrm{g}), \mathrm{PGF}_{2 \alpha}(750 \mu \mathrm{g})$ $7 \mathrm{~d}$ later, GnRH $(100 \mu \mathrm{g}) 56 \mathrm{~h}$ after $\mathrm{PGF}_{2 \alpha}$, and TAI 16 to $20 \mathrm{~h}$ later. All cows in the HGPG group received an intramuscular injection of hCG $(2,000 \mathrm{IU}$ of hCG, Chorulon; Intervet Inc., Millsboro, DE) 18 d after TAI, and $7 \mathrm{~d}$ later they began the D25 Resynch $(\mathrm{n}=450)$ protocol similar to cows in the control treatment. Pregnancy diagnosis was performed $29 \mathrm{~d}$ after TAI by using transrectal US, similar to the other 2 treatments. Cows failing to conceive to a TAI service were rerandomized to treatments and inseminated until they conceived or were removed from the herd before the study was concluded.

\section{Experiment 1: Pregnancy Diagnosis, Ovarian US, and Ovulatory Responses}

Pregnancy diagnoses and ovarian US $29 \mathrm{~d}$ after TAI were performed by using a portable scanner (Easi-Scan, BCF Technology Ltd., Livingston, UK) fitted with a 7.5-MHz linear array transducer. The herd veterinarian performed pregnancy diagnoses at $53 \mathrm{~d}$ after TAI by transrectal palpation of the uterine contents. For all cows, pregnancy diagnosis was performed $29 \mathrm{~d}$ after TAI regardless of their resynchronization treatment to compare $\mathrm{P} / \mathrm{AI}$ and pregnancy loss at similar time points between resynchronization treatments. All cows diagnosed pregnant $29 \mathrm{~d}$ after TAI were reevaluated using transrectal palpation $53 \mathrm{~d}$ after TAI. All cows in the D25 and HGPG Resynch groups diagnosed not pregnant $29 \mathrm{~d}$ after TAI continued the protocol to receive $\mathrm{PGF}_{2 \alpha} 32 \mathrm{~d}$ after TAI, as described previously.

In a subgroup of cows from the D25 and HGPG Resynch treatments $(\mathrm{n}=92)$, transrectal US was performed to record the number and size of structures present on the ovaries for subsequent determination of ovulatory response to hCG (18 d after TAI) and GnRH (25 d after TAI) treatment and cyclicity sta- 
tus at $11,18,25$, and $32 \mathrm{~d}$ after TAI. Follicle and CL diameter was estimated and recorded using on-screen background gridlines comprising squares with $10-\mathrm{mm}$ sides in the portable scanner. Ultrasonography was performed for cows in both treatments to determine the presence or absence of a CL and the diameter of follicles present on the ovaries. Seven days later, ovarian US was performed to determine the ovulatory response to hCG or GnRH. Ovulation was defined as the presence of a follicle $\geq 10 \mathrm{~mm}$ at the initial US scanning and the presence of a new or an additional CL in the same location $7 \mathrm{~d}$ later at the second US examination. When necessary, P4 concentration was used as an aid to determine ovulatory response.

\section{Experiment 1: Blood Sampling and Progesterone Analysis}

In the same subgroup of D25 and HGPG cows ( $\mathrm{n}=$ 98), blood samples were collected via puncture of the median caudal vein or artery into evacuated tubes with no anticoagulant (Vacutainer; BD, Franklin Lakes, $\mathrm{NJ}$ ) at 11, 18, 25, and $32 \mathrm{~d}$ after TAI to determine P4 concentrations. Blood samples were transported to the laboratory in an insulated cooler within 2 to $3 \mathrm{~h}$ of collection and centrifuged at $4^{\circ} \mathrm{C}(2,000 \times g, 20 \mathrm{~min})$, and serum was harvested and stored at $-20^{\circ} \mathrm{C}$ until assayed for $\mathrm{P} 4$ concentrations using a solid-phase, no-extraction
RIA (Coat-a-Count; Diagnostic Products Corporation, Los Angeles, CA). Average sensitivity for the $3 \mathrm{P} 4$ assays was $0.03 \mathrm{ng} / \mathrm{mL}$. The intraassay $\mathrm{CV}$ was $7.5 \%$, whereas the interassay CV was $4.0 \%$.

\section{Experiment 2: Treatments}

For experiment 2, the D25 and HGPG treatments described in experiment 1 were compared, whereas the DO Resynch treatment was discontinued. The third treatment consisted of replacing the $\mathrm{hCG}$ injection $18 \mathrm{~d}$ after TAI in the HGPG protocol with a GnRH injection $(200 \mu \mathrm{g}$ of gonadorelin, Fertagyl). The new protocol differed from the HGPG protocol by substituting GnRH $7 \mathrm{~d}$ before initiation of the D25 Resynch protocol (GGPG). Figure 2 illustrates the design for experiment 2. Cows failing to conceive to a TAI service were rerandomized to treatments and inseminated until they conceived or were removed from the herd before the study was concluded.

\section{Experiment 2: Pregnancy Diagnosis, Ovarian US, and Ovulatory Responses}

Pregnancy diagnoses and ovarian US were performed as in experiment 1 except that the first pregnancy diagnosis was performed $32 \mathrm{~d}$ after TAI. All cows diagnosed pregnant $32 \mathrm{~d}$ after TAI were reevaluated us-

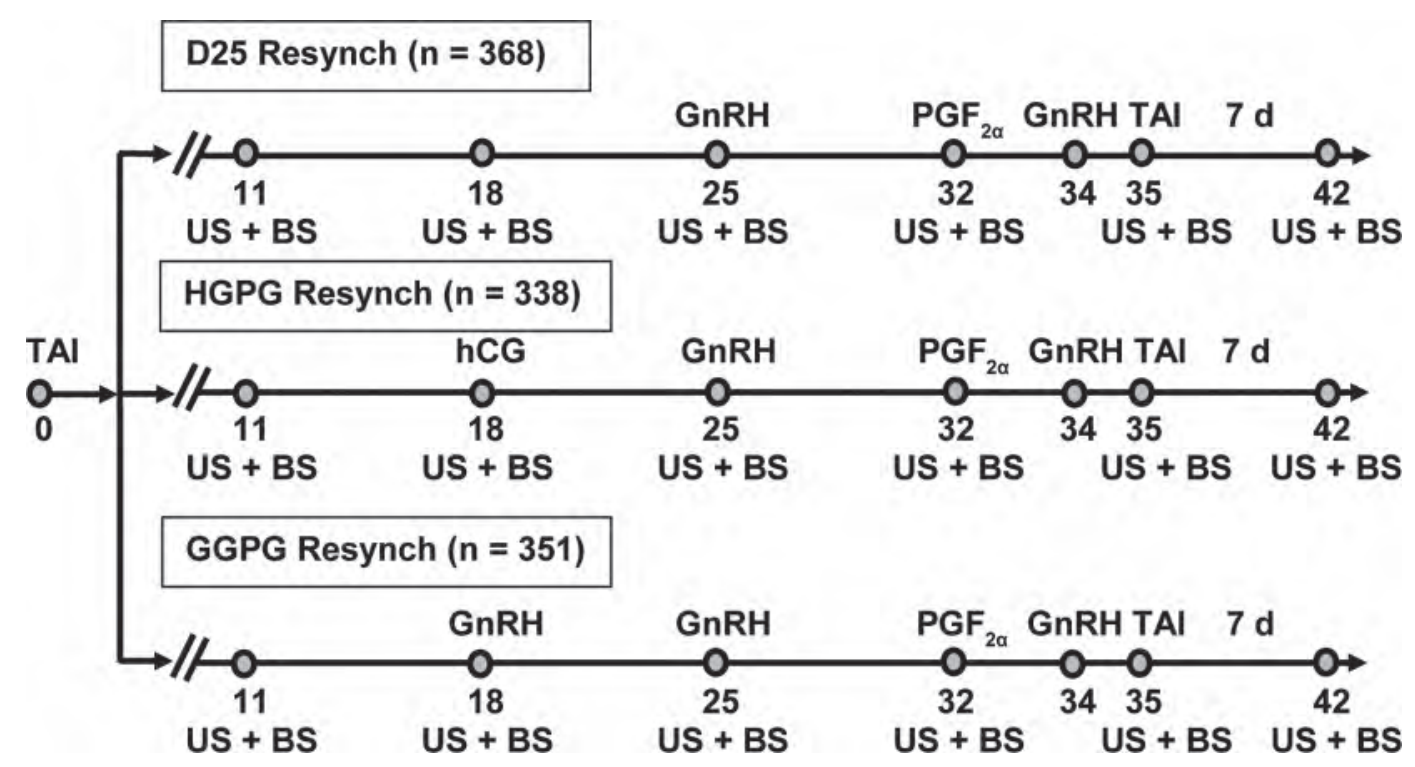

Figure 2. Schematic representation of treatments for experiment 2. Eleven days after a previous AI service, cows were randomly assigned to resynchronization of ovulation with the Ovsynch protocol $25 \mathrm{~d}$ after a previous timed AI (TAI; D25 Resynch), presynchronization with hCG 7 d before beginning D25 (HGPG Resynch), or presynchronization with GnRH 7 d before beginning D25 (GGPG Resynch) to receive their subsequent TAI service. Ovarian ultrasound (US) was performed in a subgroup of cows ( $\mathrm{n}=169)$ from the 3 treatments at 11 , 18,25 , and 32 d after TAI to record the number and size of structures present on the ovaries, and blood samples (BS) were collected to determine progesterone (P4) concentrations. In another subgroup of cows $(\mathrm{n}=545)$, blood samples were collected at the time of PGF $2 \alpha$, AI, and $7 \mathrm{~d}$ after TAI to determine $\mathrm{P} 4$ concentrations. 
ing transrectal palpation $53 \mathrm{~d}$ after TAI by the herd veterinarian.

Similar to experiment 1, in a subgroup of cows from the 3 treatments $(\mathrm{n}=169)$, transrectal US was performed to determine the ovulatory response to hCG and $\mathrm{GnRH}$ treatment $18 \mathrm{~d}$ after TAI and then to the GnRH injection $25 \mathrm{~d}$ after TAI. Ovarian US was also performed to aid in the determination of cyclicity status at 11, 18, 25, and $32 \mathrm{~d}$ after TAI. Additionally, ovarian US was performed in another subset of cows $(\mathrm{n}=545)$ to determine cyclicity status $32 \mathrm{~d}$ after the previous TAI and at the time of resynchronized TAI and $7 \mathrm{~d}$ later to determine the ovulatory response to the last GnRH injection before TAI in all 3 treatments.

\section{Experiment 2: Blood Sampling and Progesterone Analysis}

In a subgroup of cows $(\mathrm{n}=169)$ from the 3 treatments, blood samples were collected 11, 18, 25, and $32 \mathrm{~d}$ after TAI to determine P4 concentrations as described for experiment 1. From another subset of cows $(\mathrm{n}=545)$, blood samples were collected at the $\mathrm{PGF}_{2 \alpha}$ injection of Resynch and at TAI to determine the $\mathrm{P} 4$ concentration at $\mathrm{PGF}_{2 \alpha}$ and subsequent luteal regression. In the same subset of cows, blood samples were collected $7 \mathrm{~d}$ after TAI to assess P4 concentration to be used as an aid in the determination of ovulation around the time of AI. All blood samples were handled and analyzed as described in experiment 1 . Average sensitivity for the $14 \mathrm{P} 4$ assays was $0.02 \mathrm{ng} / \mathrm{mL}$. The intraassay CV was $5.4 \%$, whereas the interassay $\mathrm{CV}$ was $7.7 \%$.

\section{Calculation of Percentage of Cows with Their Estrous Cycle Synchronized}

To determine the cumulative effect of individual injections of each Resynch protocol, the percentage of cows with their estrous cycle synchronized was calculated in the subgroup of cows $(\mathrm{n}=545)$ with data available for $\mathrm{P} 4$ concentration at the time of $\mathrm{PGF}_{2 \alpha}$, TAI, and $7 \mathrm{~d}$ after TAI as well as the ovulatory response to the last GnRH before TAI. Cows were considered to have their estrous cycle synchronized when they had high P4 $(\geq 1.0 \mathrm{ng} / \mathrm{mL})$ before $\mathrm{PGF}_{2 \alpha}$ administration, had low $\mathrm{P} 4$ after $\mathrm{PGF}_{2 \alpha}$ administration at TAI $(<0.2 \mathrm{ng} / \mathrm{mL})$, and responded to the GnRH before TAI by ovulating a follicle.

\section{Statistical Analyses}

Experiment 1. The experimental design was a randomized complete block design with parity (primipa- rous vs. multiparous) as the blocking factor. Analyses of binary response data (P/AI and pregnancy loss) were performed by logistic regression using the GLIMMIX procedure of SAS (version 9.2; SAS Institute Inc., Cary, NC). For P/AI at 29 and $53 \mathrm{~d}$ after TAI, the initial model contained the following categorical explanatory variables as fixed effects: treatment (D25 vs. DO vs. HGPG), parity (primiparous vs. multiparous), AI number $(2,3, \geq 4)$, resynchronization treatment at the time of pregnancy diagnosis (D25 vs. DO vs. HGPG), and AI technician (1 vs. 2) as well as the interactions between treatment and parity, and treatment and AI number. The resynchronization treatment at the time of pregnancy diagnosis was included in the statistical model to test the potential effect of administering either hCG or GnRH injections after a previous TAI on the outcome of that TAI service. Given that the experimental unit was the AI breeding after resynchronization, all initial models contained both fixed and random effects. Fixed effects included in the initial models were the classification variables treatment, parity, AI number, resynchronization treatment at pregnancy diagnosis, AI technician, and the interactions between treatment and parity, and treatment and AI number, whereas cow was included as a random effect to account for any potential variation owing to cows receiving multiple AI breedings. On the basis of a covariance parameter estimate test, the random effect of cow was removed from the model so that all final models contained only fixed effects. The covariance parameter test using the ZeroG option for the GLIMMIX procedure was used to evaluate whether the matrix containing random effects could be reduced to zero. A covariance parameter test based on the residual pseudo-likelihood was run, and a nonsignificant chi-squared $P$-value indicated that random effects could be eliminated from the model (SAS Documentation for GLIMMIX, SAS version 9.2). After removing the random effects, selection of the fixed effects model that best fit the data for each variable of interest was performed by finding the model with the lowest value for the Akaike information criterion using a backward elimination procedure that removed all variables with $P>0.10$ from the model. Both treatment and parity were forced to remain in each model. Parity was kept in the final models because it was used as a blocking factor for randomization of cows to treatments. Therefore, for P/AI at 29 and $53 \mathrm{~d}$ after AI, the final model contained the fixed effects of treatment and parity.

For analysis of pregnancy loss, the same categorical variables and interactions used for $\mathrm{P} / \mathrm{AI}$ were used to obtain the models for pregnancy loss from 29 to $53 \mathrm{~d}$ after AI. The procedures and criteria used for model 
selection were similar to those used for $\mathrm{P} / \mathrm{AI}$. The final model included the effects of treatment, parity, and AI number.

Data collected from the subgroup of cows sampled for $\mathrm{P} 4$ concentration at 11,18 , and $25 \mathrm{~d}$ after TAI were used to determine the percentage of cows with a functional CL $(\geq 1 \mathrm{ng} / \mathrm{mL}$ of P4) at each time point throughout the experiment. The difference in the percentage of cows with high or low $\mathrm{P} 4$ at each time point was determined by logistic regression using PROC GLIMMIX of SAS. The logistic regression model contained the fixed effects of resynchronization treatment and parity. Differences in $\mathrm{P} 4$ concentration at $25 \mathrm{~d}$ after TAI were analyzed by ANOVA using PROC MIXED of SAS with a model that contained the fixed effects of resynchronization treatment and parity. Before this analysis, normality of the data was assessed using the Shapiro-Wilk statistic, Q-Q plots, and probability plots. When these analytical methods suggested a lack of normality of the data distribution, data transformations were attempted to correct the lack of normality. Because of nonnormality of the data for P4 concentrations at $25 \mathrm{~d}$ after TAI, data were $\log$-transformed. The ovulatory responses to hCG $18 \mathrm{~d}$ after TAI and then to GnRH $25 \mathrm{~d}$ after TAI were analyzed by logistic regression using PROC GLIMMIX of SAS. The models to assess the ovulatory response to hCG and GnRH contained the fixed effects of resynchronization treatments, parity, and the classification variable $\mathrm{P} 4$ concentration (high vs. low; 1.0 $\mathrm{ng} / \mathrm{mL}$ cutoff) either 18 or $25 \mathrm{~d}$ after TAI.

Experiment 2. The experimental design for experiment 2 was also a randomized complete block design with parity as the blocking factor. Analyses of binary response data (P/AI, pregnancy loss) were performed similar to experiment 1 except that the variable season of AI service was introduced into the model for testing. For the classification of inseminations by season, AI services occurring from June 25, 2009, to September 10, $2009(\mathrm{n}=500)$, were considered to occur during the warm season, whereas AI services occurring from September 17, 2009, to December 3, 2009 ( $\mathrm{n}=557$ ), were considered to occur during the cool season. The initial model for P/AI at 32 and $53 \mathrm{~d}$ after TAI and pregnancy loss contained as fixed effects the same categorical variables and interactions used for the analysis in experiment 1 except that the variable season and the treatment $\times$ season interaction were added. The final model for $\mathrm{P} / \mathrm{AI}$ at 32 and $53 \mathrm{~d}$ after TAI contained treatment, parity, AI number, and season as fixed effects, whereas the final model for pregnancy loss contained treatment, parity, and AI number.

Data collected from the subgroup of cows $(\mathrm{n}=169)$ sampled for $\mathrm{P} 4$ concentration at 11, 18, and $25 \mathrm{~d}$ after TAI and the ovulatory response to hCG and GnRH 18 and $25 \mathrm{~d}$ after TAI were analyzed similarly to those described for experiment 1.

Finally, data from the subgroup of cows $(\mathrm{n}=545)$ with available information for $\mathrm{P} 4$ concentration at $\mathrm{PGF}_{2 \alpha}$ and GnRH before TAI as well as the ovulatory response to the GnRH injection before TAI for the 3 resynchronization treatments were used to evaluate and compare the percentage of cows that had their estrous cycle synchronized and $\mathrm{P} / \mathrm{AI}$ after completion of both treatments. Both percentage of cows and P/AI were calculated and compared for the different intermediate classification groups created sequentially as follows: cows with low versus high $\mathrm{P} 4$ at the time of the $\mathrm{PGF}_{2 \alpha}$ injection, with low versus high $\mathrm{P} 4$ at the $\mathrm{GnRH}$ before TAI (indicative of luteal regression), with ovulatory response to the GnRH injection before TAI, and synchronized or not synchronized to the protocols (synchronized vs. nonsynchronized). Statistical differences for the percentage of cows and P/AI for the different treatments were analyzed by logistic regression using either PROC GLIMMIX or PROC LOGISTIC of SAS. Receiver operating characteristic (ROC) analysis was used to determine the cutoff value for $\mathrm{P} 4$ at the time of $\mathrm{AI}$ (72 $\mathrm{h}$ after $\mathrm{PGF}_{2 \alpha}$ ), with the highest area under the ROC curve reflecting the highest combination of sensitivity and specificity for the occurrence of pregnancy and nonpregnancy. Cows were then classified as having either high or low P4 (indicative of complete luteal regression) at this time based on the cutoff value.

A significant difference between the levels of a classification variable was considered when $P<0.05$, whereas differences between $P \geq 0.05$ and $P \leq 0.10$ were considered a statistical tendency. Further, the least significant difference post hoc means separation test was used to determine differences between least squares means. Data included in the text are presented as arithmetic means $( \pm \mathrm{SE})$ obtained using PROC MEANS or percentages obtained with PROC FREQ of SAS, whereas estimates of least squares means and standard errors of the means $( \pm \mathrm{SEM})$ are reported in the tables.

\section{RESULTS AND DISCUSSION}

\section{Effect of Treatment on Fertility}

In experiment 1 , at $29 \mathrm{~d}$ after resynchronized TAI, cows in the DO and HGPG groups had more $(P<$ 0.01) $\mathrm{P} / \mathrm{AI}$ than cows in the D25 group (Table 1 ), and they did not differ $(P=0.42)$ between primiparous and multiparous cows or AI service number $(P=0.98)$. Moreover, initiating resynchronization treatments before the pregnancy diagnosis (cows received either 1 GnRH injection when enrolled in D25 and DO Resynch 
Table 1. Effect of treatment on pregnancies per AI (P/AI) at 29 and $53 \mathrm{~d}$ after timed AI (TAI) and pregnancy loss from 29 to $53 \mathrm{~d}$ after TAI for resynchronized cows in experiment 1

\begin{tabular}{lcccc}
\hline & \multicolumn{3}{c}{ Treatment $^{1}$} \\
\cline { 2 - 4 } Item & D25 & DO & HGPG & $P$-value \\
\hline P/AI 29 d, \% (no./no.) & $28.0(117 / 418)$ & $35.8(145 / 405)$ & $37.3(168 / 450)$ & \\
LSM \pm SEM & $27.9 \pm 2.2^{\mathrm{b}}$ & $35.8 \pm 2.4^{\mathrm{a}}$ & $37.2 \pm 2.2^{\mathrm{a}}$ & $<0.01$ \\
$\mathrm{P} / \mathrm{AI} 53$ d, \% (no./no.) & $25.4(106 / 417)$ & $33.4(135 / 404)$ & $32.6(145 / 445)$ & \\
LSM \pm SEM & $25.4 \pm 2.1^{\mathrm{b}}$ & $33.4 \pm 2.3^{\mathrm{a}}$ & $32.5 \pm 2.2^{\mathrm{a}}$ & 0.02 \\
Loss 29 to 53 d, \% (no./no.) & $8.6(10 / 116)$ & $6.3(9 / 144)$ & $11.0(18 / 163)$ & 0.25 \\
LSM \pm SEM & $7.8 \pm 2.5$ & $5.1 \pm 1.8$ & $10.1 \pm 2.4$ & $0.1 \pm$ \\
\hline
\end{tabular}

${ }^{a, b}$ Within a row, means with different superscripts differ $(P<0.05)$.

${ }^{1}$ Cows were resynchronized for the second and subsequent AI services by starting the Ovsynch protocol $25 \mathrm{~d}$ after a previous TAI (D25, control), the Double-Ovsynch Resynch protocol (DO) beginning $22 \mathrm{~d}$ after a previous TAI, or presynchronization with human chorionic gonadotropin $7 \mathrm{~d}$ before beginning D25 (HGPG).

or 1 hCG injection when enrolled in HGPG Resynch) did not affect $(P=0.29) \mathrm{P} / \mathrm{AI}$ to the previous insemination $(\mathrm{D} 25=31.7 \%$; DO $=38.0 \%$, and $\mathrm{HGPG}=$ $32.3 \%)$. At $53 \mathrm{~d}$ after TAI, cows in the DO and HGPG groups had more $(P=0.02) \mathrm{P} / \mathrm{AI}$ than cows in the D25 group (Table 1 ), and $\mathrm{P} / \mathrm{AI}$ did not differ $(P=0.52)$ between primiparous and multiparous cows.

Pregnancy loss from 29 to $53 \mathrm{~d}$ after TAI was not affected $(P=0.25)$ by resynchronization treatment (Table 1$)$ or parity $(P=0.67)$. An effect $(P=0.01)$ of AI number was detected for pregnancy loss from 29 to $53 \mathrm{~d}$ after TAI, in which cows receiving their second AI had greater pregnancy loss (14.5\%) than cows receiving their third (5.2\%), and fourth or greater AI (5.1\%).

In experiment 2 , at $32 \mathrm{~d}$ after TAI, $\mathrm{P} / \mathrm{AI}$ was greater $(P=0.03)$ for cows in the HGPG group than for those in the D25 group, whereas cows in the GGPG group had intermediate $\mathrm{P} / \mathrm{AI}$ (Table 2). In addition, at $32 \mathrm{~d}$ after TAI, $\mathrm{P} / \mathrm{AI}$ did not differ $(P=0.17)$ between primiparous and multiparous cows, tended to differ $(P=0.06)$ by $\mathrm{AI}$ number $(33.7,25.9$, and $29.2 \%$ for second, third, and fourth or greater AI services, respectively), and were greater $(P<0.01)$ during the cool than during the warm season (33.9 vs. $25.8 \%$, respectively). Moreover, initiating resynchronization treatments before the pregnancy diagnosis (cows received either $1 \mathrm{GnRH}$ injection when enrolled in D25, 2 GnRH injections when enrolled in GGPG Resynch, or $1 \mathrm{hCG}$ and $1 \mathrm{GnRH}$ injection when enrolled in HGPG Resynch) did not affect $(P=$ $0.96) \mathrm{P} / \mathrm{AI}$ to the previous insemination (D25 $=27.4 \%$; $\mathrm{GGPG}=30.6 \%$, and $\mathrm{HGPG}=31.6 \%)$. At $53 \mathrm{~d}$ after TAI, P/AI tended to be greater $(P=0.09)$ for cows in the HGPG group than for those in the D25 group, whereas $\mathrm{P} / \mathrm{AI}$ for cows in the GGPG group did not differ from those in the other 2 treatments (Table 2 ). Pregnancies per AI at $53 \mathrm{~d}$ after TAI also tended to differ $(P=0.05)$ by AI service number $(31.7,24.2$, and $26.4 \%$ for the second, third, and fourth or greater AI services, respectively) and were greater $(P<0.01)$ for cows receiving AI during the cool season than during the warm season (31.5 vs. $23.7 \%$, respectively). Pregnancy loss from 32 to $53 \mathrm{~d}$ after TAI was not affected $(P=0.20)$ by resynchronization treatment (Table 2$)$, did not differ $(P=0.82)$ between primiparous and multiparous cows, and was not affected by AI service number $(P=0.49)$.

The results of these 2 experiments support our overall hypothesis that presynchronizing the estrous cycle

Table 2. Effect of treatment on pregnancies per AI (P/AI) at 32 and $53 \mathrm{~d}$ after timed AI (TAI) and pregnancy loss from 32 to $53 \mathrm{~d}$ after TAI for resynchronized cows in experiment 2

\begin{tabular}{lcccc}
\hline & \multicolumn{3}{c}{ Treatment $^{1}$} \\
\cline { 2 - 4 } Item & D25 & HGPG & GGPG & P-value \\
\hline P/AI 32 d, \% (no./no.) & $25.5(94 / 368)$ & $33.7(114 / 338)$ & $31.6(111 / 351)$ & \\
LSM \pm SEM & $24.2 \pm 2.2^{\mathrm{b}}$ & $32.8 \pm 2.6^{\mathrm{a}}$ & $30.3 \pm 2.5^{\mathrm{ab}}$ & 0.03 \\
$\mathrm{P} / \mathrm{AI} 53$ d, \% (no./no.) & $24.0(88 / 366)$ & $31.3(105 / 336)$ & $28.5(100 / 351)$ & \\
LSM \pm SEM & $23.1 \pm 2.2$ & $30.4 \pm 2.5$ & $27.3 \pm 2.4$ & 0.09 \\
Loss 32 to 53 d, \% (no./no.) & $3.3(3 / 91)$ & $6.3(7 / 112)$ & $9.9(11 / 111)$ & 0.20 \\
LSM \pm SEM & $3.3 \pm 1.9$ & $6.3 \pm 2.3$ & $9.9 \pm 2.8$ & \\
\hline
\end{tabular}

$\overline{\mathrm{a}, \mathrm{b}}$ Within a row means with different superscripts differ $(P<0.05)$.

${ }^{1}$ Cows were resynchronized for second and subsequent AI services by starting the Ovsynch protocol $25 \mathrm{~d}$ after a previous TAI (D25, control), presynchronization with human chorionic gonadotropin $7 \mathrm{~d}$ before beginning D25 (HGPG), or presynchronization with GnRH 7 d before beginning D25 (GGPG). 
before initiation of a resynchronization of ovulation protocol would increase the fertility of resynchronized dairy cows. Previous studies from our laboratory (Silva et al., 2007; Lopes et al., 2011; Giordano et al., 2012c) and by others (Dewey et al., 2010) have reported an increase in $\mathrm{P} / \mathrm{AI}$ with the use of different presynchronization strategies before the initiation of either Ovsynch or Cosynch protocols for resynchronization. Conversely, another study reported no benefits of such an approach on P/AI (Alkar et al., 2011). Taken together, the results of these studies suggest that when a single hormone injection is used to induce ovulation for presynchronization, fertility is generally improved. In the present study, treatment with hCG $18 \mathrm{~d}$ after TAI to presynchronize the estrous cycle increased P/AI ( 8 to 9 percentage points) compared with nonpresynchronized cows. It is interesting that cows resynchronized with hCG had P/AI similar to cows that received a modified Ovsynch protocol for presynchronization (i.e., the DO Resynch protocol). By contrast, because both improvement (Dewey et al., 2010) and lack of improvement (Alkar et al., 2011) in P/AI have been reported in studies using a single $\mathrm{GnRH}$ injection for presynchronization, the response to GnRH appears to be less consistent among studies than the response to hCG.

In experiment 1 , cows in both the DO and HGPG groups had greater $\mathrm{P} / \mathrm{AI}$ than did cows in the D25 group, which were not presynchronized. It is interesting that cows in the DO and HGPG groups had similar $\mathrm{P} / \mathrm{AI}$, suggesting that replacing the Ovsynch protocol with a single hCG injection $7 \mathrm{~d}$ before the initiation of Resynch may be a viable approach to presynchronize the estrous cycle of cows for second and subsequent AI. Moreover, when compared with DO, the HGPG protocol had the advantage of a 14-d shorter interbreeding interval. In the context of the reproductive efficiency of a dairy herd, increasing $\mathrm{P} / \mathrm{AI}$ via a single injection to presynchronize the estrous cycle while having a $35-\mathrm{d}$ interbreeding interval may have a major effect on the rate at which cows become pregnant after first AI. In addition, resynchronization programs that have shorter interbreeding intervals can be more economically profitable than other programs that result in superior fertility but with longer interbreeding intervals (Giordano et al., 2011).

The results of experiment 2, which was designed to test whether hCG could be replaced by treatment with GnRH 18 d after TAI, also supported the overall hypothesis of improved P/AI after presynchronization of the estrous cycle. It is interesting that when compared with the results of experiment 1, a similar improvement in $\mathrm{P} / \mathrm{AI}(\sim 8$ percentage points) $32 \mathrm{~d}$ after TAI was observed for cows presynchronized with hCG. Con- versely, the improvement ( $\sim 6$ percentage points) in $\mathrm{P} /$ AI for cows presynchronized with GnRH did not reach statistical significance, suggesting that treatment with GnRH 18 d after TAI was not as effective as treatment with hCG. A slightly greater improvement in P/AI ( 9 percentage points) was observed by Dewey et al. (2010) after presynchronization with GnRH $7 \mathrm{~d}$ before beginning Cosynch at a nonpregnancy diagnosis performed $39 \pm 3 \mathrm{~d}$ after a previous AI. Thus, differences between the results of our study and those of Dewey et al. (2010) are manifold. For example, differences in timing of the presynchronization protocol (18 vs. $32 \mathrm{~d}$ after AI, respectively) may have affected the ovulatory response to the GnRH injection, as well as the fact that $100 \%$ of cows received TAI in our study, whereas only cows not detected in estrus after the previous AI completed the resynchronization protocol in the study by Dewey et al. (2010). It is also possible that presynchronization with GnRH may be more beneficial when using a Cosynch rather than an Ovsynch-56 protocol. In contrast, Alkar et al. (2011) reported no effect of presynchronization on $\mathrm{P} / \mathrm{AI}$ when cows were presynchronized with a $\mathrm{GnRH}$ injection $7 \mathrm{~d}$ before Cosynch-72 initiated at $35 \pm 3 \mathrm{~d}$ after a previous AI. In the studies of both Alkar et al. (2011) and Dewey et al. (2010), the resynchronization of ovulation protocols was identical except that in the former study, the first GnRH injection was given to cows $4 \mathrm{~d}$ earlier. Therefore, the discrepancies between these 2 studies and the results of experiment 2 may suggest that the benefit of presynchronizing cows with GnRH is dependent on the timing of the protocol, with the best results obtained when the presynchronizing $\mathrm{GnRH}$ injection is given around $32 \mathrm{~d}$ after a previous AI.

It has been well documented that the fertility of lactating dairy cows is impaired during periods of heat stress (Fricke et al., 2003; Chebel et al., 2004; Giordano et al., 2012c) because of the alteration of multiple physiological processes (Hansen and Arechiga, 1999). Therefore, it was not surprising to observe overall lower $\mathrm{P} / \mathrm{AI}$ for cows artificially inseminated during the warm season than during the cool season in experiment 2, which began during the summer months. Despite the lack of a treatment $\times$ season interaction, $\mathrm{P} / \mathrm{AI}$ at $32 \mathrm{~d}$ after TAI for cows in the GGPG group had the greatest variation attributable to season, with a 12-percentagepoint difference, as opposed to cows in the HGPG and D25 groups, which had less variation (Table 3). Thus, heat stress may have had a greater detrimental effect on GnRH-induced LH release (Gilad et al., 1993), which in turn resulted in a lower ovulatory response that precluded the beneficial effect of presynchronization. More important, GnRH might be a good alternative to $\mathrm{hCG}$ 
Table 3. Effect of season within each of the treatments in experiment 2 on pregnancies per AI (P/AI) at 32 and 53 d after timed AI (TAI) for resynchronized cows

\begin{tabular}{|c|c|c|c|c|c|c|}
\hline Item & \multicolumn{6}{|c|}{ Treatment $^{1}$} \\
\hline $\begin{array}{l}\text { P/AI } 32 \text { d, }{ }^{2} \% \text { (no./no.) } \\
\text { LSM } \pm \text { SEM } \\
\text { P/AI } 53 \mathrm{~d}^{3} \% \text { (no. } / \text { no.) } \\
\text { LSM } \pm \text { SEM }\end{array}$ & $\begin{array}{c}21.4(38 / 178) \\
20.6 \pm 3.0^{\mathrm{b}} \\
19.9(35 / 176) \\
19.3 \pm 3.0^{\mathrm{b}}\end{array}$ & $\begin{aligned} 29.0(55 / 190) \\
28.2 \pm 3.3^{\mathrm{a}} \\
27.9(53 / 190) \\
27.3 \pm 3.3^{\mathrm{a}}\end{aligned}$ & $\begin{aligned} 31.5 & (50 / 159) \\
30.3 & \pm 3.7^{\mathrm{b}} \\
29.1 & (46 / 158) \\
28.1 & \pm 3.6^{\mathrm{b}}\end{aligned}$ & $\begin{aligned} 35.8 & (64 / 179) \\
35.8 & \pm 3.6^{\mathrm{a}} \\
33.2 & (59 / 178) \\
33.3 & \pm 3.6^{\mathrm{a}}\end{aligned}$ & $\begin{aligned} 25.2 & (41 / 163) \\
24.2 & \pm 3.4^{\mathrm{b}} \\
22.7 & (37 / 163) \\
21.8 & \pm 3.2^{\mathrm{b}}\end{aligned}$ & $\begin{aligned} 37.2(70 / 188) \\
36.6 \pm 3.6^{\mathrm{a}} \\
33.5(63 / 188) \\
33.1 \pm 3.5^{\mathrm{a}}\end{aligned}$ \\
\hline
\end{tabular}

${ }^{\mathrm{a}, \mathrm{b}}$ Within each resynchronization treatment, means with different superscripts differ by season $(P<0.05)$.

${ }^{1}$ Cows were resynchronized for the second and subsequent AI services by starting the Ovsynch protocol $25 \mathrm{~d}$ after a previous TAI (D25, control), presynchronization with human chorionic gonadotropin $7 \mathrm{~d}$ before beginning D25 (HGPG), or presynchronization with GnRH $7 \mathrm{~d}$ before beginning D25 (GGPG).

${ }^{2}$ Pregnancies per AI at $32 \mathrm{~d}$ were affected by treatment $(P=0.03)$ and season $(P<0.01)$ and tended $(P=0.07)$ to differ by AI number. The effect of parity $(P=0.18)$ and the treatment $\times$ season interaction $(P=0.57)$ were not significant.

${ }^{3}$ Pregnancies per AI at $53 \mathrm{~d}$ after was affected by season $(P<0.01)$ and tended to be affected by treatment $(P=0.08)$ and AI number $(P=$ 0.06). The effect of parity $(P=0.24)$ and the treatment $\times$ season interaction $(P=0.62)$ were not significant.

during cool seasons because the P/AI for cows in the GGPG group was similar to that of cows presynchronized using hCG.

The tendency for $\mathrm{P} / \mathrm{AI}$ to decrease with $\mathrm{AI}$ service number in experiment 2 was unexpected and contrasted with the findings from experiment 1 . To some extent, the effect of AI number on $\mathrm{P} / \mathrm{AI}$ is contentious because previous studies have also reported decreased $\mathrm{P} /$ AI (Chebel et al., 2004) or no effect (Giordano et al., 2012c) of AI service number on $\mathrm{P} / \mathrm{AI}$.

\section{Endocrine and Ovarian Parameters After a Previous TAI}

Overall, the percentage of cows with a functional CL $(\mathrm{P} 4 \geq 1 \mathrm{ng} / \mathrm{mL}) 11 \mathrm{~d}$ after TAI for cows in both experiments was $90 \%$ (241/267; Figure 3A), and these cows had a mean P4 concentration of $3.1 \pm 0.1 \mathrm{ng} /$ $\mathrm{mL}$. Of the cows that had a CL $11 \mathrm{~d}$ after TAI, $21 \%$ underwent luteal regression by $18 \mathrm{~d}$ after TAI based on $\mathrm{P} 4$ concentration. At $18 \mathrm{~d}$ after TAI, the percentage of cows with a functional CL was 74\% (197/267; Figure $3 \mathrm{~B}$ ), and these cows had a mean $\mathrm{P} 4$ concentration of $3.3 \pm 0.1 \mathrm{ng} / \mathrm{mL}$.

Under normal physiological conditions, a high percentage of cows should have a functional CL by $18 \mathrm{~d}$ after a previous AI. Indeed, combined data from both experiments showed that more than $70 \%$ of cows still had a functional CL and mean P4 $>3.0 \mathrm{ng} / \mathrm{mL}$ by 18 $\mathrm{d}$ after TAI. The rationale behind the use of hCG $18 \mathrm{~d}$ after TAI in both experiments 1 and 2 was to overcome the suppressive effect of $\mathrm{P} 4$ on $\mathrm{LH}$ release from the pituitary (Colazo et al., 2008; Dias et al., 2010; Giordano et al., 2012a), which in turn suppresses ovulation (Stevenson et al., 2008; Giordano et al., 2012c). Unlike
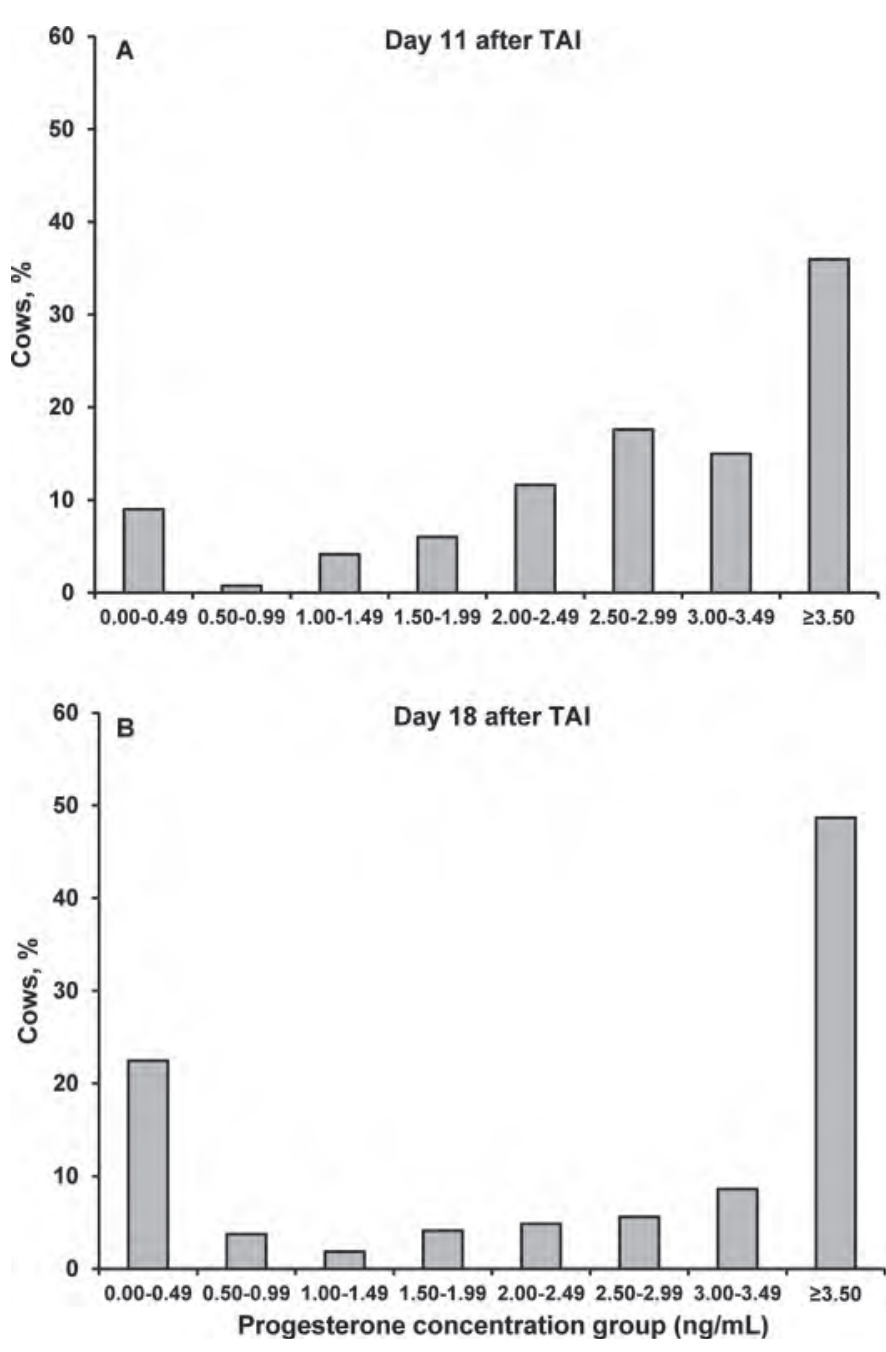

Figure 3. Distribution of cows $(\mathrm{n}=267)$ from experiments 1 and 2 according to progesterone (P4) at $11 \mathrm{~d}(\mathrm{~A})$ and $18 \mathrm{~d}(\mathrm{~B})$ after timed AI (TAI). 
Table 4. Ovulation from d 18 to 25 and d 25 to 32 after timed AI (TAI) and percentage of cows with progesterone $(\mathrm{P} 4) \geq 1.0 \mathrm{mg} / \mathrm{mL}$ at 25 and $32 \mathrm{~d}$ after TAI for cows in experiment 1

\begin{tabular}{lccc}
\hline & \multicolumn{2}{c}{ Treatment $^{1}$} & \\
\cline { 2 - 3 } Item & D25 & HGPG & $P$-value \\
\hline Ovulation d 18 to 25, \% (no./no.) & $11.9(5 / 42)$ & $76.0(38 / 50)$ & \\
LSM \pm SEM & $10.0 \pm 4.9$ & $88.8 \pm 5.4$ & $<0.01$ \\
P4 $\geq 1.0 \mathrm{ng} / \mathrm{mL}$ d 25, \% (no./no.) & $31.8(14 / 44)$ & $77.1(37 / 48)$ & \\
LSM \pm SEM & $31.8 \pm 7.0$ & $77.1 \pm 6.1$ & $<0.01$ \\
Ovulation d 25 to 32, \% (no./no.) & $70.5(31 / 44)$ & $43.5(20 / 46)$ & 0.14 \\
LSM \pm SEM & $68.3 \pm 7.6$ & $50.0 \pm 8.7$ & 0.7 \\
\hline
\end{tabular}

${ }^{1}$ Cows were resynchronized for the second and subsequent AI services by starting the Ovsynch protocol 25 d after a previous TAI (D25, control) or presynchronization with human chorionic gonadotropin $7 \mathrm{~d}$ before beginning D25 (HGPG).

the indirect mechanism of action of GnRH to induce ovulation, hCG has a direct effect on follicles by triggering the ovulatory process through binding directly to LH receptors on granulosa cells (Ireland and Roche, 1982, 1983).

In experiment 1 , the ovulatory response from d 18 to 25 after TAI was greater for cows in the HGPG group than for those in the D25 group $(P<0.01$; Table 4$)$ and was affected by $\mathrm{P} 4(P=0.03)$. Overall, the ovulatory response for cows with $\geq 1.0 \mathrm{ng} / \mathrm{mL}$ of P4 was $45 \%(30 / 67)$ compared with $52 \%(13 / 25)$ for cows with $<1.0 \mathrm{ng} / \mathrm{mL}$ of $\mathrm{P} 4$. In addition, primiparous cows $(50 \%, 22 / 44)$ tended to have a greater $(P=0.05)$ ovulatory response than did multiparous cows $(44 \%$, $21 / 48)$. In experiment 2 , the ovulatory response from $d$ 18 to 25 after TAI was greater for cows in the HGPG and GGPG groups than for those in the D25 group ( $P$ $<0.01$; Table 5) and was affected by $\mathrm{P} 4(P=0.01)$. Overall, the ovulatory response for cows with $\geq 1.0$ $\mathrm{ng} / \mathrm{mL}$ of $\mathrm{P} 4$ was $32 \%(39 / 122)$ compared with $53 \%$ $(24 / 45)$ for cows with $<1.0 \mathrm{ng} / \mathrm{mL}$ of $\mathrm{P} 4$. A treatment $\times$ P4 interaction, which would indicate a lack of an effect of $\mathrm{P} 4$ on the ovulatory response to hCG, was not significant $(P=0.42)$. A primary hypothesis of these experiments was that presynchronization of the estrous cycle with a single injection of either hCG or GnRH would induce ovulation $18 \mathrm{~d}$ after TAI, thereby increasing the percentage of cows with a functional CL at the initiation of the Resynch protocol $25 \mathrm{~d}$ after TAI. Indeed, hCG induced ovulation in 76 and $59 \%$ of the cows in experiments 1 and 2, respectively, whereas GnRH induced ovulation in $48 \%$ of the cows in experiment 2. These data confirm that both hCG and GnRH are capable of inducing ovulation, albeit to a different extent, when administered $18 \mathrm{~d}$ after a previous TAI.

In experiment $1, \mathrm{P} 4$ concentrations $25 \mathrm{~d}$ after TAI were greater $(P<0.01)$ for cows in the HGPG group than for those in the D25 group ( $3.4 \pm 0.5$ vs. $1.3 \pm 0.3$, respectively) and did not differ $(P=0.55)$ between primiparous and multiparous cows. Likewise, the percentage of cows with $\geq 1.0 \mathrm{ng} / \mathrm{mL}$ of $\mathrm{P} 4$ was affected $(P<$ 0.01 ; Table 4$)$ by treatment but was similar $(P=0.93)$ for primiparous and multiparous cows. The ovulatory response to the GnRH injection 25 d after TAI was similar $(P=0.14)$ for cows in the D25 and HGPG groups (Table 4) and for primiparous versus multiparous cows $(P=0.13)$. Furthermore, the ovulatory response was greater $(P=0.03)$ for cows with $\mathrm{P} 4<1.0 \mathrm{ng} / \mathrm{mL}(75 \%$, $30 / 40)$ than for cows with $\geq 1.0 \mathrm{ng} / \mathrm{mL}$ of $\mathrm{P} 4(42 \%$, $21 / 50$ ) at the time of GnRH injection. The percentage

Table 5. Ovulation from d 18 to 25 and d 25 to 32 after timed AI (TAI) and percentage of cows with progesterone $(\mathrm{P} 4) \geq 1.0 \mathrm{mg} / \mathrm{mL}$ at 25 and $32 \mathrm{~d}$ after TAI for cows in experiment 2

\begin{tabular}{|c|c|c|c|c|}
\hline \multirow[b]{2}{*}{ Item } & \multicolumn{3}{|c|}{ Treatment $^{1}$} & \multirow[b]{2}{*}{$P$-value } \\
\hline & D25 & HGPG & GGPG & \\
\hline Ovulation d 18, \% (no./no.) & $11.3(7 / 62)^{\mathrm{b}}$ & $58.8(30 / 51)^{\mathrm{a}}$ & $48.2(26 / 54)^{\mathrm{a}}$ & \\
\hline $\mathrm{LSM} \pm \mathrm{SEM}$ & $14.9 \pm 5.2$ & $70.9 \pm 7.2$ & $60.0 \pm 7.7$ & $<0.01$ \\
\hline $\mathrm{P} 4 \geq 1.0 \mathrm{ng} / \mathrm{mL} \mathrm{d} 25, \%$ (no./no.) & $46.8(29 / 62)$ & $64.2(34 / 53)$ & $54.5(30 / 55)$ & \\
\hline $\mathrm{LSM} \pm \mathrm{SEM}$ & $46.7 \pm 6.4$ & $64.0 \pm 6.7$ & $54.5 \pm 6.7$ & 0.19 \\
\hline Ovulation d 25 GnRH, \% (no./no.) & $54.2(32 / 59)$ & $52.0(26 / 50)$ & $64.8(35 / 54)$ & \\
\hline $\mathrm{LSM} \pm \mathrm{SEM}$ & $54.6 \pm 6.5$ & $53.6 \pm 7.5$ & $66.4 \pm 6.8$ & 0.34 \\
\hline
\end{tabular}


of cows with follicles $\geq 10 \mathrm{~mm}$ at the time of injection did not differ $(P=0.51)$ between treatments (93 vs. 90\% for HGPG and D25 cows, respectively).

In experiment 2, P4 concentrations $25 \mathrm{~d}$ after TAI did not differ $(P=0.45)$ among cows because of treatment $(2.3 \pm 0.3,2.1 \pm 0.3$, and $2.0 \pm 0.3$ for cows in the D25, HGPG, and GGPG Resynch treatments, respectively) and did not differ by parity $(P=0.52)$. Additionally, the percentage of cows with $\geq 1.0 \mathrm{ng} / \mathrm{mL}$ of $\mathrm{P} 4$ was not affected $(P=0.19$; Table 5$)$ by treatment and did not differ $(P=0.86)$ between primiparous and multiparous cows. The ovulatory response to $\mathrm{GnRH}$ treatment $25 \mathrm{~d}$ after TAI did not differ $(P=0.34$; Table $5)$ among cows in the 3 treatments and did not differ $(P$ $=0.86$ ) by parity. Furthermore, ovulatory response was not affected $(P=0.18)$ by $\mathrm{P} 4$ at the time of treatment. The percentage of cows with follicles $\geq 10 \mathrm{~mm}$ did not differ $(P=0.99)$ among treatments $(90,100$, and $100 \%$ for cows in the D25, HGPG, and GGPG treatments, respectively).

The hypothesis that presynchronization would increase the percentage of cows with a functional CL at initiation of the Resynch protocols was supported by data from experiment 1 for the use of hCG but was not supported by data from experiment 2 for either hCG or GnRH. In experiment 1 , hCG dramatically increased the percentage of cows with a functional CL and $\mathrm{P} 4$ concentrations at the first GnRH injection of Resynch $25 \mathrm{~d}$ after TAI. Almost $80 \%$ of cows had a functional CL when presynchronized with hCG $7 \mathrm{~d}$ earlier, whereas fewer (32\%) nonpresynchronized D25 cows had a functional CL. For D25 cows, these observations may be explained, at least in part, by the timing of US evaluation. It is possible that by $25 \mathrm{~d}$ after a previous TAI, some cows may have recently regressed their CL but not yet ovulated, or alternatively, that ovulation occurred within 1 to $3 \mathrm{~d}$ of sampling and the CL was not producing much $\mathrm{P} 4$. The latter is a very likely scenario because the average duration of the estrous cycle in lactating dairy cows is $22.9 \pm 0.7 \mathrm{~d}$ rather than $21 \mathrm{~d}$ (Sartori et al., 2004). In experiment 2, despite the fact that an additional $17 \%$ of cows in the HGPG group had a functional CL $25 \mathrm{~d}$ after TAI, this difference was not statistically significant. Similarly, P4 was not affected by treatment at this time. Therefore, it seems that the lack of difference may have been due to a lesser ovulatory response to hCG in cows in the HGPG group or to a greater percentage of cows with either incomplete luteal regression or ovulation by at least 3 to $4 \mathrm{~d}$ before blood sample collection $25 \mathrm{~d}$ after TAI in cows in the D25 group. Indeed, in groups of lactating dairy cows previously inseminated and failing to conceive, both situations have been reported (Giordano et al., 2012b).
The percentage of cows in the GGPG group with a functional CL 25 d after TAI was intermediate between cows in the D25 and HGPG groups, and P4 concentrations were similar to those of the other treatments. Even though these results were obtained from few cows in the present experiments, results suggest that 200 $\mu \mathrm{g}$ of $\mathrm{GnRH}$ may not be as effective as 2,000 IU of hCG for presynchronizing cows $18 \mathrm{~d}$ after AI. Further research is needed to confirm these observations. In contrast, Dewey et al. (2010) reported that treatment with GnRH $7 \mathrm{~d}$ before enrollment in the Cosynch-72 protocol for resynchronization tended to increase the number of cows with a functional CL and increased the number of CL per cow. Similar observations were made by Alkar et al. (2011) after presynchronization with GnRH. Nevertheless, results from the latter study should be interpreted with caution because of the low number of cows evaluated and the lack of statistical comparisons between treatments.

The ovulatory response to the first GnRH injection of the Resynch protocols $25 \mathrm{~d}$ after TAI did not differ between treatments in either experiment; however, it was affected by $\mathrm{P} 4$ in experiment 1 but not in experiment 2. Overall, the percentage of cows ovulating in both experiments $(\sim 57 \%)$ was either similar (Silva et al., 2007) or greater than those reported in previous studies (Dewey et al., 2010; Giordano et al., 2012c). We speculated that few cows would have follicles with ovulatory capacity at this time, considering an average interovulatory interval of $22.9 \mathrm{~d}$ in lactating dairy cows (Sartori et al., 2004). It was surprising that more than $90 \%$ of cows had at least 1 follicle $>10 \mathrm{~mm}$ in diameter, the minimum ovulatory size in lactating dairy cows (Sartori et al., 2001). In addition, the greater ovulatory response after $\mathrm{GnRH}$ treatment might have resulted from using $200 \mu \mathrm{g}$ of $\mathrm{GnRH}$ instead of the labeled dose of $100 \mu \mathrm{g}$. We chose to use an increased GnRH dose because ovulatory response was increased by using 200 $\mu \mathrm{g}$ compared with $100 \mu \mathrm{g}$ of GnRH (Giordano et al., 2009). It is also possible that the ovulatory response to $\mathrm{GnRH}$ treatment 25 d after TAI may have been slightly overestimated because of spontaneous ovulations occurring a few days before $\mathrm{GnRH}$ treatment and not detected by US. The suppressive effect of $\mathrm{P} 4$ on ovulation in experiment 1 agrees with results from cows treated $18 \mathrm{~d}$ after TAI as well as with reports from other studies (Stevenson et al., 2008; Buttrey et al., 2010; Giordano et al., 2012c) and may have been the result of P4 suppression on GnRH-induced LH secretion (Colazo et al., 2008; Dias et al., 2010; Giordano et al., 2012a). By contrast, the lack of difference in the ovulatory response between cows with high versus low $\mathrm{P} 4$ (despite a clear trend for a greater ovulatory response 
Table 6. Effect of treatment on ovarian and endocrine parameters in lactating Holstein cows during the resynchronization of ovulation protocols

\begin{tabular}{|c|c|c|c|c|}
\hline \multirow[b]{2}{*}{ Item } & \multicolumn{3}{|c|}{ Treatment $^{1}$} & \multirow[b]{2}{*}{$P$-value } \\
\hline & $\begin{array}{c}\text { D25, \% } \\
\text { (no./no.) }\end{array}$ & $\begin{array}{c}\text { HGPG, \% } \\
\text { (no./no.) }\end{array}$ & $\begin{array}{c}\text { GGPG, \% } \\
\text { (no./no.) }\end{array}$ & \\
\hline \multicolumn{5}{|l|}{$\mathrm{P} 4$ at time of $\mathrm{PGF}_{2 \alpha}{ }^{2}$} \\
\hline Cows with low $\mathrm{P} 4$ & $22.4(41 / 183)$ & $15.2(28 / 184)$ & $16.3(29 / 178)$ & 0.16 \\
\hline $\mathrm{P} / \mathrm{AI}^{3}$ for cows with low $\mathrm{P} 4$ & $17.1(7 / 41)$ & $21.4(6 / 28)$ & $6.9(2 / 29)$ & 0.32 \\
\hline $\mathrm{P} / \mathrm{AI}$ for cows with high $\mathrm{P} 4$ & $30.3(43 / 142)$ & $34.6(54 / 156)$ & $33.6(50 / 149)$ & 0.71 \\
\hline $\mathrm{P} / \mathrm{AI}$ for cows with high $\mathrm{P} 4$ & $8.1(3 / 37)$ & $9.5(2 / 21)$ & $10.3(3 / 29)$ & 0.95 \\
\hline $\mathrm{P} / \mathrm{AI}$ for cows with low $\mathrm{P} 4$ & $38.1(405 / 105)$ & $38.5(52 / 135)$ & $39.2(47 / 120)$ & 0.99 \\
\hline \multicolumn{5}{|l|}{ Ovulation to the $\mathrm{GnRH}$ before $\mathrm{TAI}^{5}$} \\
\hline Cows with no ovulation & $6.7(7 / 105)$ & $5.2(7 / 135)$ & $5.0(6 / 120)$ & 0.84 \\
\hline $\mathrm{P} / \mathrm{AI}$ for cows with no ovulation & $0.0(0 / 7)$ & $0.0(0 / 7)$ & $0.0(0 / 6)$ & 0.99 \\
\hline P/AI for cows with ovulation & $40.8(40 / 98)$ & $40.6(52 / 128)$ & $41.2(47 / 114)$ & 0.99 \\
\hline \multicolumn{5}{|c|}{ Percentage of cows with estrous cycle synchronized ${ }^{6}$} \\
\hline
\end{tabular}

${ }^{\mathrm{a}, \mathrm{b}}$ Within a row, means with different superscripts differ $(P<0.05)$.

${ }^{1}$ Cows were resynchronized for the second and subsequent AI services by starting the Ovsynch protocol 25 d after a previous timed AI (TAI; D25, control), presynchronization with human chorionic gonadotropin $7 \mathrm{~d}$ before beginning D25 (HGPG), or presynchronization with GnRH 7 d before beginning D25 (GGPG).

${ }^{2}$ The progesterone (P4) cutoff used to classify cows as having high versus low $\mathrm{P} 4$ at $\mathrm{PGF}_{2 \alpha}$ in the present experiment was $1.0 \mathrm{ng} / \mathrm{mL}$.

${ }^{3} \mathrm{P} / \mathrm{AI}=$ pregnancies per $\mathrm{AI}$.

${ }^{4}$ The $\mathrm{P} 4$ cutoff used to classify cows as having high versus low P4 at TAI in the present experiment was $0.2 \mathrm{ng} / \mathrm{mL}$.

${ }^{5}$ Ovulation was defined as the presence of a follicle $\geq 10 \mathrm{~mm}$ at the initial ultrasound (US) scanning (time of resynchronized AI) and presence of a new corpus luteum in the same location $7 \mathrm{~d}$ later at the second US examination.

${ }^{6}$ Cows were considered to have their estrous cycle synchronized according to the following criteria: $\geq 1.0 \mathrm{ng} / \mathrm{mL}$ of $\mathrm{P} 4 \mathrm{at} \mathrm{PGF} 2 \alpha,<0.2 \mathrm{ng} / \mathrm{mL}$ of $\mathrm{P} 4$ at TAI, and ovulation to GnRH before TAI

in cows with low P4) in experiment 2 was unexpected and is likely due to a type II statistical error because of the number of cows evaluated.

\section{Effect of Treatment on Response to Resynchronization Protocol Injections in Experiment 2}

For a subset of cows with complete information on multiple physiological parameters, the response to specific treatments during the synchronization protocols was evaluated (Table 6 ). At the $\mathrm{PGF}_{2 \alpha}$ injection, each treatment had a similar $(P=0.16)$ percentage of cows with $\mathrm{P} 4<1.0 \mathrm{ng} / \mathrm{mL}$ (Table 6 ), and $\mathrm{P} / \mathrm{AI}$ were equally poor for cows among the 3 treatments with $\mathrm{P} 4<1.0$ $\mathrm{ng} / \mathrm{mL}(P=0.32$; Table 6$)$.

The P4 cutoff that indicated complete luteal regression at TAI based on an ROC curve in the present experiment was $0.2 \mathrm{ng} / \mathrm{mL}$. The sensitivity and specificity were 94 and $28 \%$, respectively, and area under the ROC curve was $60 \%$. After eliminating cows with low $\mathrm{P} 4(<1.0 \mathrm{ng} / \mathrm{mL})$ at $\mathrm{PGF}_{2 \alpha}$, a greater percentage of cows in the D25 and GGPG groups had high P4 $(\geq 0.2$ $\mathrm{ng} / \mathrm{mL}$ ) at TAI, indicating a greater rate of incomplete luteal regression compared with cows in the HGPG group, and these cows had few $\mathrm{P} / \mathrm{AI}$ (Table 6). After eliminating cows with high $\mathrm{P} 4$ at TAI $(\geq 0.2 \mathrm{ng} / \mathrm{mL})$, cows that had high $\mathrm{P} 4$ at the $\mathrm{PGF}_{2 \alpha}$ injection $(\geq 1.0$ $\mathrm{ng} / \mathrm{mL}$ ) and that had complete luteal regression at TAI $(<0.2 \mathrm{ng} / \mathrm{mL})$ were analyzed for the ovulatory response to the final $\mathrm{GnRH}$ injection of the resynchronization protocols. Treatment did not affect $(P=0.82)$ the proportion of cows failing to ovulate to the final $\mathrm{GnRH}$ injection of the protocols. None of the cows failing to ovulate to the GnRH treatment was diagnosed pregnant $32 \mathrm{~d}$ after TAI (Table 6). Therefore, on the basis of the criteria used to classify cows that responded to or failed to respond to the resynchronization protocols $\left(\geq 1.0 \mathrm{ng} / \mathrm{mL}\right.$ of $\mathrm{P} 4$ at $\mathrm{PGF}_{2 \alpha},<0.2 \mathrm{ng} / \mathrm{mL}$ of $\mathrm{P} 4$ at TAI, and ovulation to GnRH before TAI), a greater ( $P$ $<0.01$ ) percentage of cows in the HGPG and GGPG groups were synchronized compared with cows in the D25 group (Table 6). Overall, P/AI for cows that were not synchronized were lower than $\mathrm{P} / \mathrm{AI}$ for synchronized cows and did not differ between treatments for both nonsynchronized $(P=0.51)$ and synchronized cows $(P=0.99$; Table 6$)$.

The ultimate goal of synchronization of ovulation protocols is to maximize the number of cows that respond adequately to each of the hormonal injections 
to ensure a properly synchronized ovulation for TAI. Regardless of the treatment applied, optimal fertility after TAI is achieved when cows respond appropriately to the hormonal injections of the protocol (Giordano et al., 2012c). It is interesting that a greater percentage of cows presynchronized with either hCG or GnRH responded to each of the injections of the resynchronization protocols ( $\mathrm{PGF}_{2 \alpha}$ and second GnRH of Resynch), which may explain in part the improvement in fertility observed in experiment 2 for cows in the HGPG group. Pregnancies per AI $32 \mathrm{~d}$ after TAI in cows that responded to each injection of the protocols were 7 to 14 percentage points greater than the mean for the treatments including all cows and were significantly greater than P/AI of cows that were not synchronized. These findings agree with those of Giordano et al. (2012c) and suggest that a major reason for poor $\mathrm{P} / \mathrm{AI}$ in resynchronized cows is a lack of synchronization to the protocol.

\section{CONCLUSIONS}

Presynchronization of the estrous cycle with hCG 7 $\mathrm{d}$ before initiating resynchronization of ovulation $25 \mathrm{~d}$ after TAI induced ovulation and increased P/AI when compared with nonpresynchronized cows. Furthermore, the fertility observed in cows presynchronized with hCG was similar to that of cows resynchronized with a DO Resynch protocol. Replacing the hCG injection with GnRH did not increase P/AI when compared with that of nonpresynchronized cows. Presynchronization with hCG increased fertility by increasing synchronization to the protocol. We conclude that presynchronization with hCG $7 \mathrm{~d}$ before the start of a resynchronization program initiated $25 \mathrm{~d}$ after a previous TAI improved the fertility of lactating dairy cows while resulting in a shorter interbreeding interval than other protocols that have been reported for resynchronization of ovulation in lactating dairy cows.

\section{ACKNOWLEDGMENTS}

The authors thank Spring Grove Dairy (Brodhead, WI) and their staff for providing their cows and facilities for this study. This research was supported by Hatch project WIS01171 funding to P.M.F.

\section{REFERENCES}

Alkar, A., A. Tibary, J. R. Wenz, R. L. Nebel, and R. Kasimanickam. 2011. Presynchronization with GnRH 7 days prior to resynchronization with CO-Synch did not improve pregnancy rate in lactating dairy cows. Theriogenology 76:1036-1041.
Bello, N. M., J. P. Steibel, and J. R. Pursley. 2006. Optimizing ovulation to first $\mathrm{GnRH}$ improved outcomes to each hormonal injection of Ovsynch in lactating dairy cows. J. Dairy Sci. 89:3413-3424.

Buttrey, B. S., M. G. Burns, and J. S. Stevenson. 2010. Ovulation and pregnancy outcomes in response to human chorionic gonadotropin before resynchronized ovulation in dairy cattle. Theriogenology 73:449-459.

Chebel, R. C., J. E. Santos, J. P. Reynolds, R. L. Cerri, S. O. Juchem, and M. Overton. 2004. Factors affecting conception rate after artificial insemination and pregnancy loss in lactating dairy cows. Anim. Reprod. Sci. 84:239-255.

Colazo, M. G., J. P. Kastelic, H. Davis, M. D. Rutledge, M. F. Martinez, J. A. Small, and R. J. Mapletoft. 2008. Effects of plasma progesterone concentrations on LH release and ovulation in beef cattle given GnRH. Domest. Anim. Endocrinol. 34:109-117.

Dewey, S. T., L. G. Mendonca, G. Lopes Jr., F. A. Rivera, F. Guagnini, R. C. Chebel, and T. R. Bilby. 2010. Resynchronization strategies to improve fertility in lactating dairy cows utilizing a presynchronization injection of GnRH or supplemental progesterone: I. Pregnancy rates and ovarian responses. J. Dairy Sci. 93:4086-4095.

Dias, F. C., M. G. Colazo, J. P. Kastelic, R. J. Mapletoft, G. P. Adams, and J. Singh. 2010. Progesterone concentration, estradiol pretreatment, and dose of gonadotropin-releasing hormone affect gonadotropin-releasing hormone-mediated luteinizing hormone release in beef heifers. Domest. Anim. Endocrinol. 39:155-162.

El-Zarkouny, S. Z., J. A. Cartmill, B. A. Hensley, and J. S. Stevenson. 2004. Pregnancy in dairy cows after synchronized ovulation regimens with or without presynchronization and progesterone. J. Dairy Sci. 87:1024-1037.

Fricke, P. M., D. Z. Caraviello, K. A. Weigel, and M. L. Welle. 2003. Fertility of dairy cows after resynchronization of ovulation at three intervals following first timed insemination. J. Dairy Sci. 86:3941-3950

Galvão, K. N., M. F. Sa Filho, and J. E. Santos. 2007. Reducing the interval from presynchronization to initiation of timed artificial insemination improves fertility in dairy cows. J. Dairy Sci. 90:4212-4218.

Gilad, E., R. Meidan, A. Berman, Y. Graber, and D. Wolfenson. 1993. Effect of heat stress on tonic and $\mathrm{GnRH}$-induced gonadotrophin secretion in relation to concentration of oestradiol in plasma of cyclic cows. J. Reprod. Fertil. 99:315-321.

Giordano, J. O., P. M. Fricke, S. Bas, A. P. Cunha, R. A. Pawlisch, J. N. Guenther, and M. C. Wiltbank. 2009. Effect of increasing the dose of $\mathrm{GnRH}$ and $\mathrm{PGF}_{2 \alpha}$ during Double-Ovsynch on fertility of lactating dairy cows at first postpartum timed artificial insemination. J. Dairy Sci. 92(E-Suppl. 1):264. (Abstr.)

Giordano, J. O., P. M. Fricke, J. N. Guenther, G. Lopes Jr., M. M. Herlihy, A. B. Nascimento, and M. C. Wiltbank. 2012a. Effect of progesterone on magnitude of the luteinizing hormone surge induced by two different doses of gonadotropin-releasing hormone in lactating dairy cows. J. Dairy Sci. 95:3781-3793.

Giordano, J. O., P. M. Fricke, M. C. Wiltbank, and V. E. Cabrera 2011. An economic decision-making support system for selection of reproductive management programs on dairy farms. J. Dairy Sci. 94:6216-6232.

Giordano, J. O., J. N. Guenther, G. Lopes Jr., M. F. McGrath, J. Howard, and J. R. Branen. 2012b. Changes in serum pregnancy-associated glycoprotein (PAG), pregnancy specific protein B (PSPB), and progesterone concentrations before and after induction of pregnancy loss in lactating dairy cows. J. Dairy Sci. 95:683-697.

Giordano, J. O., M. C. Wiltbank, and P. M. Fricke. 2012c. Increased fertility in lactating dairy cows resynchronized with DoubleOvsynch when compared with Ovsynch initiated $32 \mathrm{~d}$ after timed AI. J. Dairy Sci. 95:639-653.

Hansen, P. J., and C. F. Arechiga. 1999. Strategies for managing reproduction in the heat-stressed dairy cow. J. Anim. Sci. 77(Suppl. 2):36-50.

Ireland, J. J., and J. F. Roche. 1982. Development of antral follicles in cattle after prostaglandin-induced luteolysis: Changes in serum 
hormones, steroids in follicular fluid, and gonadotropin receptors. Endocrinology 111:2077-2086.

Ireland, J. J., and J. F. Roche. 1983. Growth and differentiation of large antral follicles after spontaneous luteolysis in heifers: Changes in concentration of hormones in follicular fluid and specific binding of gonadotropins to follicles. J. Anim. Sci. 57:157-167.

Lopes, G., Jr, J. O. Giordano, A. Valenza, M. M. Herlihy, J. G. Guenther, M. C. Wiltbank, and P. M. Fricke. 2011. Effect of timing of initiation of Resynch and presynchronization with $\mathrm{GnRH}$ on fertility of resynchronized inseminations in lactating dairy cows. J. Dairy Sci. 94(E-Suppl. 1):237. (Abstr.)

Moreira, F., C. Orlandi, C. A. Risco, R. Mattos, F. Lopes, and W. W. Thatcher. 2001. Effects of presynchronization and bovine somatotropin on pregnancy rates to a timed artificial insemination protocol in lactating dairy cows. J. Dairy Sci. 84:1646-1659.

NRC (National Research Council). 2001. Nutrient Requirements of Dairy Cattle. 7th ed. Natl. Acad. Sci., Washington, DC.

Navanukraw, C., D. A. Redmer, L. P. Reynolds, J. D. Kirsch, A. T. Grazul-Bilska, and P. M. Fricke. 2004. A modified presynchronization protocol improves fertility to timed artificial insemination in lactating dairy cows. J. Dairy Sci. 87:1551-1557.

Pursley, J. R., M. O. Mee, and M. C. Wiltbank. 1995. Synchronization of ovulation in dairy cows using $\mathrm{PGF}_{2 \alpha}$ and $\mathrm{GnRH}$. Theriogenology $44: 915-923$.
Sartori, R., P. M. Fricke, J. C. Ferreira, O. J. Ginther, and M. C. Wiltbank. 2001. Follicular deviation and acquisition of ovulatory capacity in bovine follicles. Biol. Reprod. 65:1403-1409.

Sartori, R., J. M. Haughian, R. D. Shaver, G. J. Rosa, and M. C. Wiltbank. 2004. Comparison of ovarian function and circulating steroids in estrous cycles of Holstein heifers and lactating cows. J. Dairy Sci. 87:905-920.

Silva, E., R. A. Sterry, D. Kolb, M. C. Wiltbank, and P. M. Fricke. 2007. Effect of pretreatment with prostaglandin F2alpha before resynchronization of ovulation on fertility of lactating dairy cows. J. Dairy Sci. 90:5509-5517.

Souza, A. H., H. Ayres, R. M. Ferreira, and M. C. Wiltbank. 2008. A new presynchronization system (Double-Ovsynch) increases fertility at first postpartum timed AI in lactating dairy cows. Theriogenology 70:208-215.

Stevenson, J. S., D. E. Tenhouse, R. L. Krisher, G. C. Lamb, J. E. Larson, C. R. Dahlen, J. R. Pursley, N. M. Bello, P. M. Fricke, M. C. Wiltbank, D. J. Brusveen, M. Burkhart, R. S. Youngquist, and H. A. Garverick. 2008. Detection of anovulation by heatmount detectors and transrectal ultrasonography before treatment with progesterone in a timed insemination protocol. J. Dairy Sci. 91:2901-2915. 